Volume 2 Nomor 2, November 2021: h. 152 - 165

P-ISSN: 2722-4465, E-ISSN: 2746-8151

Lisensi Creative Commons Atribusi-NonCommercial 4.0 Internasional

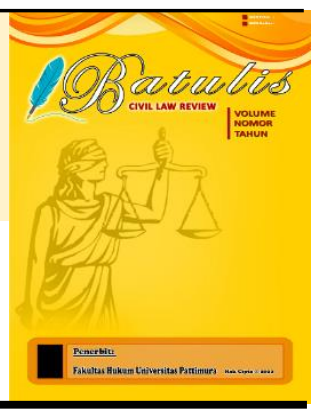

\title{
Mekanisme Pemberian Izin Mendirikan Bangunan Bagi Pembangunan Perumahan
}

\section{Zegovia Parera 1, Abrar Saleng ${ }^{2}$}

1, 2, Fakultas Hukum Universitas Hasanuddin, Makassar, Indonesia

E-mail: z3goviap4rera@gmail.com

\begin{tabular}{l}
\multicolumn{1}{c}{ Dikirim: 20/06/2021 } \\
\hline Info Artikel \\
\hline Keywords: \\
Legal Mechanism; Building \\
Permit; Housing. \\
Kata Kunci: \\
Mekanisme Hukum; Izin \\
Pendirikan Bangunan; \\
\hline
\end{tabular}

\begin{tabular}{ll} 
Direvisi: 30/10/2021 Dipublikasi: $27 / 11 / 2021$ \\
\hline Abstract
\end{tabular}

This study aims to identify and analyze statutory regulations related to building permits for the implementation of the conversion of protected areas into residential buildings and to analyze the control of spatial use of housing development in Merauke District. This research is an empirical legal research. This research was conducted at the Legal Division of the Merauke Regency Regional Secretariat, the Spatial Planning Section of the Ministry of Agrarian Affairs and Spatial Planning / National Land Agency of Merauke Regency, the Public Works and Spatial Planning Office of Merauke Regency, developers, and residential communities. The results of this study indicate that the laws and regulations related to building permits on the implementation of housing development are an obligatory affair of the regency / city government, in this case the management of buildings, which includes setting up building permits (IMB) and certificates of eligibility for building functions (SLF). new. As well as the implementation of the function change of protected areas in Samkai Village is not in accordance with the current spatial direction. For this reason, the local government of Merauke Regency is within its authority to regulate and balance the arrangement of buildings in conservation areas and water catchment areas so that the community has permits to build buildings according to the regulations. And Controlling Spatial Use of Housing Development in Protected Areas Local governments still face various obstacles / obstacles, namely not having a regional regulation on a strategic plan (renstra) for protected areas so that the government has not been able to provide certainty to the public regarding the activity plan and financing of the housing location. Supervision and control are still passive in nature because they are only based on complaints and are not carried out regularly. Most of the land in the protected area belongs to the private sector and the community, so that control is limited to an appeal.

\begin{tabular}{l} 
Abstrak \\
\hline Penelitian ini bertujuan untuk mengetahui dan menganalisis \\
peraturan perundang-undangan terkait perizinan bangunan \\
terhadap pelaksanaan alih fungsi kawasan lindung menjadi \\
bangunan perumahan dan menganalisis pengendalian \\
pemanfaatan ruang terhadap pembangunan perumahan di \\
Distrik Merauke. Penelitian ini adalah penelitian hukum empiris.
\end{tabular}


DOI:

10.47268/ballrev.v2i2.736
Penelitian ini dilakukan di Bagian Hukum Sekretariat Daerah Kabupaten Merauke, Bagian Tata Ruang Kementerian Agraria dan Tata Ruang/Badan Pertanahan Nasional Kabupaten Merauke, Dinas Pekerjaan Umum Dan Penataan Ruang Kabupaten Merauke, pengembang, dan masyarakat penghuni perumahan. Hasil penelitian ini menunjukan bahwa Peraturan Perundang-undangan terkait Perizinan Bangunan terhadap Pelaksanaan Pembangunan Perumahan merupakan urusan wajib pemerintah kabupaten/kota dalam hal ini penyelenggaraan bangunan gedung, yang termasuk di dalamnya pengaturan izin mendirikan bangunan (IMB) dan sertifikat laik fungsi (SLF) bangunan gedung baru. Serta pelaksanaan alih fungsi kawasan lindung di Kelurahan Samkai tidak sesuai arahan ruang saat ini. Untuk itu pemerintah daerah Kabupaten Merauke dalam kewenangannya alam mengatur dan menyeimbangkan penataan bangunan di kawasan konservasi dan kawasan resapan air agar masyarakat memiliki izin mendirikan bangunan yang sesuai aturan. Dan Pengendalian Pemanfaatan Ruang Terhadap Pembangunan Perumahan Pada Kawasan Lindung pemerintah daerah masih menghadapi berbagai kendala/hambatan, yaitu Belum memiliki peraturan daerah tentang rencana strategis (renstra) kawasan lindung sehingga pemerintah belum dapat memberikan kepastian ke masyarakat mengenai rencana kegiatan dan pembiayaan pada lokasi perumahan tersebut. Pengawasan dan pengendalian masih bersifat pasif karena hanya berdasarkan pengaduan dan tidak dilakukan secara berkala. Sebagian besar tanah dikawasan lindung tersebut milik swasta dan masyarakat, sehingga pengendalian hanya sebatas himbauan.

\section{Pendahuluan}

Perumahan merupakan kebutuhan dasar manusia dan mempunyai peranan yang sangat strategis dalam pembentukan watak dan kepribadian bangsa, perlu dibina dan dikembangkan demi kelangsungan dan peningkatan kehidupan dan penghidupan manusia. Perumahan tidak hanya semata-mata menjadi sarana pemenuhan kebutuhan dasar manusia, tetapi lebih dari itu dapatmenjadi tempat dalam pembentukan watak dan kepribadian bagi manusia dan peningkatan kehidupan dan penghidupan manusia.

Pada dasarnya, pemenuhan kebutuhan akan rumah sebagai tempat tinggal atau hunian merupakan tanggung jawab masyarakat itu sendiri. Namun demikian, pemerintah daerah, dan perusahaan swasta yang bergerak dalam bidang pembangunan perumahan didorong untuk dapat membantu masyarakat dalam pemenuhan kebutuhan akan rumah sebagai tempat tinggal atau hunian.

Pembangunan perumahan ditujukan agar setiap keluarga menempati rumah yang layak dalam lingkungan yang sehat, aman, serasi, dan teratur. Rumah yang layak adalah bangunan rumah yang sekurang-kurangnya memenuhi persyaratan keselamatan bangunan dan kecukupan minimum luas bangunan serta kesehatan penghuninya. Dalam pembangunan perumahan diperlukan perutaran perundang- 
undangan yang menjadi dasar hokum, kebijakan, arahan, dan pedoman dalam pelaksanaan pembangunan perumahan dan menjadi dasar hokum dalam penyelesaian masalah, kasus, dan sengketa di bidang peumahan sehingga tidak menimbulkan kerugian.

Semua orang dalam berbagai lapisan dan kelompok masyarakat berkepentingan langsung atas pemanfaatan tanah. Itulah sebabnya masalah tanah selalu bersifat multiaspek dan multikompleks, sehingga memerlukan pengaturan dan penataan yang baik dan mendasar guna mengeliminasi, setidaknya meminimalisasi konflik berkaitan dengan tanah (Wahid, 2016: 199).

Tanah sebagai ruang pada dasarnya tidak dapat bertambah. Penambahan hanya mungkin dengan skala tak terbatas akibat suatu peristiwa alamiah tertentu atau akibat campur tangan teknologi. Sebaliknya secara alamiah pula kebutuhan pemakaian tanah selalu bertambah. Menghadapi kemungkinan kesenjangan tersebut, tanah harus dipergunakan seefisien dan seefektif mungkin. Untuk itu harus ada pengaturan dan sistem pengelolaan yang baik atas tanah. Penataan ruang, perencanaan dan program, system pelekatan hak, termasuk pula kewajiban untuk menjamin kelestarian harus diatur dan dikelola dengan baik. Hal-hal hal-hal tersebut dapat dicapai apabila didukung oleh sistem dan tata administrasi Pertanahan yang baik pula (Saleng, 2013: 138-139).

Sistem dan tata administrasi tanah meliputi berbagai aspek, antara lain:

a) Sistem dan tata administrasi perencanaan dan program pertanahan.

b) Sistem dan tata administrasi peruntukan atas tanah.

c) Sistem dan tata administrasi perlindungan kelestarian tanah.

d) Sistem dan tata administrasi yang bertalian dengan hak-hak atas tanah.

Dari empat sistem dan tata administrasi di atas kegiatan administrasi yang bersangkutan dengan hak-hak atas tanah yang sangat nampak dalam kegiatan sehari-hari, karena merupakan pelayanan terhadap rakyat banyak (public service). Kegiatan ini dilakukan oleh pejabat administrasi yang memiliki wewenang mencatat peralihan atau penetapan hak atas tanah, atau mencatat suatu hak atas tanah.

Dari uraian tersebut dapat disimak bahwa tanah merupakan bagian kehidupan masyarakat dan bahkan bagian dari kehormatan suatu masyarakat. Manusia hidup untuk mendiami bumi ini tentunya mendiami dan menguasai tanah, untuk mendiami dan menguasai tanah manusia harus mampu memanfaatkannya secara baik dan optimal. Tentunya hal ini akan terjadi bila dalam prosesnya manusia bertindak dan berlaku menurut aturan-aturan, hak-hak dan kewajiban-kewajiban yang diselaraskan dengan keberadaan dan proporsinya masing-masing (Arisaputra, 2015: 58-59).

Bangunan merupakan salah satu wujud fisik pemanfaatan ruang. Oleh karena itu dalam pengaturan bangunan tetap mengacu pada pengaturan penataan ruang sesuai peraturan perundang-undangan yang berlaku. Untuk menjamin kepastian dan ketertiban hukum dalam penyelenggaraan bangunan. Setiap bangunan harus memenuhi persyaratan administratif dan teknis bangunan, serta harus 
diselenggarakan secara tertib. Pengaturan penyelenggaraan bangunan dilandasi oleh asas kemanfaatan, keselamatan, keseimbangan, dan keserasian bangunan dengan lingkungannya, bagi kepentingan masyarakat yang berperikemanusiaan dan berkeadilan.

Dalam hal melakukan kontrol terhadap masyarakat dalam hal pembangunan, dilakukan pengendalian dari pembangunan tersebut dengan adanya aturan setiap pembangunan harus dilaksanakan berdasarkan izin, berarti setiap pembangunan yang terjadi harus melalui izin pemerintah, untuk melaksanakan pembangunan tempat tinggal diperlukan izin yang dikenal dengan Izin Mendirikan Bangunan (IMB).

Adapun prosedur yang harus dilakukan oleh seseorang dari mulainya melakukan permohonan kepada pemerintah diatur secara jelas dan sesuai dengan permintaan izin yang dibutuhkan. Izin adalah suatu keputusan administrasi negara yang memperkenankan suatu perbuatan yang pada umumnya dilarang, tetapi diperkenankan dan bersifat konkrit. Izin yang dikeluarkan oleh pemerintah dalam hal mendukung pembangunan dimaksudkan untuk menciptakan lingkungan yang postitif terhadap aktivitas pembangunan itu sendiri terutama di wilayah yang terdampak adanya pembangunan tersebut.

Hukum memegang peranan penting dalam usaha menjembatani dan digunakan untuk menyelesaikan masalah secara adil, serta diharap mampu mencegah munculnya masalah dalam penyelenggaraan pemerintah yang berada di daerah. Kontrol hukum tidak hanya berlaku jika ada masalah, melainkan juga diperlukan guna memberikan kepastian hukum bagi masyarakat.

Terutama dalam hal menerbitkan izin mendirikan bangunan (IMB), karena dalam kenyataannya, beberapa pemohon izin mendirikan bangunan bahkan tidak mempedulikan aturan yang berlaku di suatu daerah perihal aturan pendirian bangunan karena hal ini tidak dapat lepas dari pengawasannya (Soedarso, 1990). Hal inilah yang kerap kali menjadi masalah, karena pemerintah daerah memberikan izin dan bahkan mengeluarkan izin terhadap bangunan yang seharusnya secara data tidak layak diberikan izin karena struktur bangunan mereka menyalahi aturan yang ada.

Kawasan lindung menurut Undang-Undang No. 26 Tahun 2007 tentang Penataan Ruang didefinisikan sebagai wilayah yang ditetapkan dengan fungsi utama melindungi kelestarian lingkungan hidup yang mencakup sumber daya alam dan sumber daya buatan berupa kawasan yang memberikan pelindungan kawasan bawahannya, kawasan perlindungan setempat, kawasan suaka alam dan cagar budaya, kawasan rawan bencana alam, dan kawasan lindung lainnya. Adanya berbagai aktivitas manusia yang dilakukan di kawasan lindung seringkali menjadi ancaman atau mengganggu keseimbangan lingkungan dan berdampak buruk bagi kawasan sekitarnya. Seperti halnya di perkotaan dengan karakteristik pembangunan yang pesat, pertumbuhan populasi yang tinggi dan kebutuhan perumahan semakin meningkat telah memaksa kota untuk meluas tak terkendali, orang- orang membangun rumah mereka ditempat-tempat yang tersedia, ekspansi ke pinggiran 
kota. Hal tersebut menjadi faktor penyebab tekanan atau sebagai ancaman utama terhadap keberadaan kawasan lindung dan pembangunan perumahan telah muncul sebagai pendorong utama perubahan penggunaan lahan di seluruh dunia.

Fenomena di atas telah bermunculan di Distrik Meruke Kab. Merauke. Sejalan dengan hal tersebut, maraknya pembangunan perumahan dan urban sprawl bahkan juga telah terjadi di kelurahan Samkai. Pada bagian-bagian dari kelurahan ini terdapat Kawasan Lindung yang ditetapkan sebagai kawasan resapan air untuk kepentingan penyelamatan lingkungan hidup seluas 449, 42 Ha melalui Peraturan Daerah Kab. Merauke No. 10 Tahun 2016 tentang Rencana Detail Tata Ruang Wilayah Perkotaan Merauke Tahun 2017 - 2037.

Saat ini sudah bermunculan pembangunan kawasan perumahan skala besar dengan total luasan 107.705 m2 atau sebanyak 667 unit di Kelurahan Samkai. yang dibangun pengembang perusahaan di kawasan resapan air, dimana keberadaan perumahan diketahui oleh pemerintah setempat. Selain itu, terdapat ketidakjelasan dalam prosedur arahan ruang dari Dinas Cipta Karya Pemukiman Dan Tata Ruang.

Oleh sebab itu, penting dilakukan penelitian ini yang sebelumnya belum pernah ada penelitian yang serupa di lokasi wilayah studi. Yang menjadi fokus pada penelitian ini adalah, Bagaimana PeraturanPerundang-undangan terkait Perizinan Bangunan terhadap Pelaksanaan Pembangunan Perumahan dan Bagaimana Pengendalian Pemanfaatan Ruang Terhadap Pembangunan Perumahan Pada Kawasan Lindung. Tujuan penelitian ini dapat dicapai melalui dua sasaran yaitu menganalisis Peraturan perundang-undangan kewenangan terkait perizinan bangunan terhadap pelaksanaan alih fungsi kawasan lindung menjadi bangunan perumahan dan menganalisis Pengendalian Pemanfaatan Ruang Terhadap pembangunan Perumahan.

\section{Metode Penelitian}

Penelitian ini dilaksanakan di Kabupaten Merauke, Provinsi Papua. Dengan pertimbangan bahwa Kabupaten Merauke memiliki pertumbuhan pesat di bidang permukiman serta memiliki laju pertumbuhan penduduk tinggi. Jenis penelitian yang digunakan adalah penelitian Hukum Empiris, selain mengkaji hukum secara teoritis atau normatif, juga akan mengkaji hukum dalam pelaksanaannya. Populasi dalam penelitian ini adalah aparat Pemerintah Kabupaten Merauke, Bagian Hukum Sekretariat Daerah Kabupaten Merauke, Bagian Tata Ruang Kementerian Agraria dan Tata Ruang/Badan Pertanahan Nasional Kabupaten Merauke, Dinas Pekerjaan Umum Dan Penataan Ruang Kabupaten Merauke, pengembang, dan masyarakat penghuni perumahan. Sampel sebanyak 35 orang terdiri dari 30 orang responden yaitu masyarakat dan 5 orang narasumber yang terdiri dari aparat pemerintah dan pengembang. Metode penetapan sampel adalah secara Purposive Sampling yaitu sampel yang secara sengaja dipilih dengan menggunakan kriteria-kriteria yang ditetapkan. Metode Pengumpulan Data yang digunakan dalam penelitian ini adalah a. Wawancara dengan mendatangi narasumber dan responden, dan melakukan tanya jawab langsung, tipe pertanyaannya teratur dan terstruktur. b. Dokumentasi dengan mengumpulkan data-data yang berkaitan dengan penelitian ini. Analisis 
Data Data primer dan data sekunder, dianalisis secara kualitatif dengan menggunakan landasan teori dalam menjelaskan fenomena yang ada, atau data dan informasi yang diperoleh disajikan secara deskriptif yaitu menguraikan, menggambarkan, dan menjelaskan sesuai dengan permasalahan yang erat kaitannya dengan penelitian.

\section{Hasil dan Pembahasan}

\subsection{Gambaran Umum Wilayah Distrik Merauke}

Distrik Merauke termasuk wilayah geografis Kabupaten Merauke yang merupakan wilayah bagian selatan dari Provinsi Papua. Distrik Merauke merupakan ibukota Kabupaten Merauke. Distrik Merauke terletak antara $140^{\circ} 060^{\circ}-140^{\circ} 080^{\circ}$ Bujur Timur dan $70^{\circ} 70^{\circ}-80^{\circ} 40^{\circ}$ Lintang Selatan. Distrik Merauke memiliki luas 640,91 km2 atau 3 persen dari luas wilayah Kabupaten Merauke. Distrik Merauke memiliki 11 kelurahan : Bambu Pemali, Seringgu Jaya, Mandala, Muli, Maro, Karang Indah, Rimba Jaya, Kelapa Lima, Samkai, Kamahedoga, dan Kamundu. Dan 5 kampung: Bokem, Nasem, Nggolar, dan Wasur. Kampung Wasur merupakan wilayah yang terluas, yaitu mencapai 505,99 km2 atau 30,96 persen, sedangkan Kelurahan Bambu Pemali merupakan wilayah terkecil yang hanya mencapai 3,62 $\mathrm{km} 2$ atau 0,22 persen dari luas wilayah Distrik Merauke.

Distrik Merauke dibatasi oleh bebrapa distrik dan Negara tetangga. Di sebelah utara berbatasan dengan Distrik Sota, sebelah timur berbatasan dengan Papua Nugini, sebelah selatan berbatsan dengan Distrik Naukenjerai, dan sebelah barat berbatasan dengan Distrik Semangga. Distrik Merauke merupakan dataran rendah yang memiiki ketinggian 5 sampai dengan 20 meter di atas permukaan laut.

Sedangkan jumlah penduduk Distrik Merauke berdasarkan data dari BPS tahun 2019 sebanyak 101.784 jiwa yang terdiri atas 51.637 laki-laki dan 50.147 perempuan. Seperti kondisi kota pada umumnya dimana hunian terpadat berada di pusat kota. Distrik Merauke merupakan jantung Kabupaten Merauke dan Kelurahan Rimba Jaya merupakan hunian terpadat dengan tingkat kepadatan mencapai 19. 741 jiwa per km persegi. Sedangkan tingkat kepadatan terendah berada di Kelurahan Bambu Pemali dengan jumlah penduduk 7.955 jiwa per km persegi.

\subsection{Peraturan Perundang-undangan terkait Perizinan Bangunan terhadap Pelaksanaan Pembangunan Perumahan}

Peraturan perundang-undangan terkait perizinan bangunan dapat dikategorikan menjadi 2 (dua) jenis, pertama, peraturan perundang-undangan terkait perizinan bangunan yang bersifat atribusi. Peraturan perundang-undangan yang bersifat atribusi merupakan peraturan perundang-undangan yang memberikan kewenangan kepada institusi yang bersangkutan, dalam hal ini pemerintah daerah, untuk menyusun dan menetapkan peraturan perundangundangan yang bersangkutan, dalam hal ini peraturan daerah. Kedua, peraturan perundang-undangan terkait perizinan bangunan yang bersifat delegasi. Peraturan perundang-undangan yang bersifat delegasi merupakan peraturan perundang- 
undangan yang memberikan delegasi atau amanah untuk menyusun dan menetapkan peraturan perundang-undangan turunannya, dalam hal ini peraturan daerah mengenai perizinan bangunan.

\section{a. Undang-Undang Dasar Negara Republik Indonesia Tahun 1945}

Undang-Undang Dasar Negara Republik Indonesia Tahun 1945 memberikan kewenangan kepada Pemerintah Daerah untuk menetapkan peraturan daerah. Hal ini diatur dalam Pasal 18 ayat (6) UUD Negara Republik Indonesia Tahun 1945, yang berbunyi: "Pemerintah daerah berhak menetapkan peraturan daerah dan peraturanperaturan lain untuk melaksanakan otonomi dan tugas pembantuan".

\section{b. Undang-Undang Nomor 23 Tahun 2014 tentang Pemerintah Daerah}

Berdasarkan Pasal 5 ayat (4) UU No. 23 Tahun 2014 tentang Pemerintah Daerah, penyelenggaraan urusan Pemerintah didaerah dilaksanakan berdasarkan asas desentralisasi, dekonsentrasi, dan tugas pembantuan. Desentralisasi dalam Undang-Undang No. 23 Tahun 2014 didefinisikan sebagai penyerahan urusan Pemerintah oleh pemerintah pusat kepada daerah otonom berdasarkan asas otonomi. Urusan pemerintah yang kemudian dibagikan kepada pemerintah daerah adalah urusan pemerintahan konkuren. Dalam Undang-Undang No. 23Tahun 2014 urusan Pemerintah konkuren kemudian dibagi dalam pembagian urusan pemerintahan konkuren antara pemerintah pusat dan pemerintah provinsi atau kabupaten/kota. Pembagiannya mencakup kewenangan dalam pengelolahan unsur managemen dan kewenangan dalam penyelenggaraan fungsi managemen. Kewenangan tersebut melekat pada masing-masing tingkatan atau susunan pemerintahan, kecuali jika diatur pengecualiannya.

Urusan pemerintahan yang bersifat konkuren dibedakan menjadi urusan pemerintahan wajib dan urusan pemerintahan pilihan. Salah satu urusan pemerintahan wajib yang berkaitan dengan pelayanan dasar adalah pekerjaan umum dan penataan ruang. Berdasarkan Pasal 12 ayat (1) Undang-Undang No. 23 Tahun 2014, pengaturan bangunan dan gedung dapat diklarifikasikan sebagai bagian pelayanan dasar dibidang pekerjaan umum dan penataan ruang. Pembagian urusan pemerintahan dibidang pekerjaan umum dan penataan ruang pada UndangUndang Nomor 23 Tahun 2014, urusan bangunan gedung serta penataan bangunan dan lingkungannya menjadi salah satu urusan wajib pemerintahan daerah. Dua urusan tersebut menjadi dasar yuridis bagi Pemerintah Daerah untuk mengaturnya dalam Peraturan Daerah. Urusan wajib yang menjadi urusan kabupaten/kota adalah penyelenggaraan bangunan gedung, yang termasuk dalam hal ini adalah pengaturan pemerintah dalam izin mendirikan bangunan (IMB) dan sertifikat laik fungsi (SLF) bangunan gedung baru.

Dalam hal ini, pemerintah daerah kabupaten Merauke dalam mengatur pemberian izin mendirikan bangunan menetapkan kebijakan daerah dalam Peraturan Daerah Kabupaten Merauke Nomor 12 Tahun 2014 tentang Bangunan Gedung (Lembaran Daerah Kabupaten Merauke Tahun 2014 Nomor 12).

\section{c. Undang-Undang Nomor 28 Tahun 2002 tentang Bangunan Gedung.}


Dalam Undang-Undang Republik Indonesia Nomor 28 Tahun 2002 tentang Bangunan Gedung (Lembaran Negara Republik Indonesia Tahun 2002 Nomor 134, Tambahan Lembaran Negara Republik Indonesia Nomor 4247), Bangunan gedung adalah wujud fisik hasil pekerjaan konstruksi yang menyatu dengan tempat kedudukannya, sebagian atau seluruhnya berada diatas dan/atau didalam tanah/atau air yang berfungsi sebagai tempat manusia melakukan kegiatannya baik untuk hunian atau tempat tinggal, kegiatan keagamaan, kegiatan usaha, kegiatan sosial, budaya maupun kegiatan khusus.

Ketentuan dalam Undang-Undang No. 28 Tahun 2002 tidak secara tegas mengatur wewenang dalam perizinan bangunan ditingkat daerah, namun beberapa pasal menunjukkan perlunya pengaturan yang terkait dengan perizinan bangunan, antara lain:

a. Pasal 6 ayat (2) mengatur bahwa fungsi bangunan gedung sebagaimana dimaksud dalam ayat (1) ditetapkan oleh Pemerintah Daerah dan dicantumkan dalam izin mendirikan bangunan. Sebagaimana dijelaskan dalam penjelasan Pasal 6 ayat (2) bahwa penetapan fungsi bangunan gedung tersebut diberikan dalam proses perizinan mendirikan bangunan.

b. Pasal 8 ayat (1) mengatur bahwa setiap bangunan gedung harus memiliki izin mendirikan bangunan gedung, selain itu dalam Pasal 8 ayat (4) diatur bahwa ketentuan mengenai izin mendirikan banguna diatur lebih lanjut dengan peraturan pemerintah.

c. Pasal 39 ayat (1) mengatur bahwa bangunan gedung dapat dibongkar apabila salah satunya karena tidak memiliki izin mendirikan bangunan.

d. Peraturan Pemerintah Nomor 36 Tahun 2005 tentang Peraturan Pelaksana Undang-Undang Nomor 28 Tahun 2002 tentang Bangunan Gedung.

Peraturan Pemerintah Nomor 36 Tahun 2005 menjadi salah satu landasan yuridis pengaturan peraturan daerah tentang Izin Mendirikan Bangunan karena merupakan peraturan perundang-undangan yang secara ekplisit mendelegasikan pengaturan lebih lanjut ke dalam Peraturan Daerah. Pendelegasian lebih lanjut kedalam peraturan daerah antara lain: Pasal 14 ayat (2) Peraturan Pemerintah Nomor 36 Tahun 2005 mengatur bahwa izin mendirikan bangunan gedung diberikan oleh Pemerintah Daerah, kecuali bangunan gedung fungsi khusus oleh Pemerintah, melalui proses permohonan izin mendirikan bangunan gedung. Pasal 14 ayat (2) menunjukkan adanya wewenang pemerintah kabupaten/kota dalam penerbitan izin mendirikan bangunan.

Pasal 112 ayat (1) Peraturan Pemerintah Nomor 36 Tahun 2005 menegaskan wewenang pemerintah kabupaten/kota dalam perizinan bangunan menyatakan bahwa pemerintah daerah melakukan pengawasan terhadap pelaksanaan penerapan peraturan daerah dibidang bangunan gedung melalui mekanisme penerbitan izin mendirikan bangunan gedung dan sertifikasi kelaikan fungsi bangunan gedung, serta surat persetujuan dan penetapan pembongkaran bangunan gedung. 
a. Peraturan Menteri Pekerjaan Umum Nomor 24/PRT/M2007Permen PU No. 24/PRT/M/2007 mengamanatkan bahwa pelaksanaan pedoman teknis IMB didaerah diatur lebih lanjut dengan peraturan daerah yang berpedoman pada peraturan ini. Dalam hal daerah belum mempunyai peraturan daerah tersebut, maka pelaksanaan izin mendirikan bangunan gedung berpedoman pada peraturan ini. Sedangkan bila daerah telah mempunyai peraturan daerah terkait yang ditetapkan sebelum permen ini diberlakukan, maka peraturan daerah tersebut harus menyesuaikan dengan substansi pengaturan dalam permen ini. Selama proses penyusunan dan/atau penyesuaian perda terkait tersebut. Semua peraturan perundang-undangan yang berkaitan dengan IMB dinyatakan masih berlaku sepanjang tidak bertentangan dengan permen ini.

b. Peraturan Menteri Dalam Negeri Nomor 32 Tahun 2010 tentang Pedoman Pemberian Izin Mendirikan Bangunan.Permendagri No. 32 Tahun 2010 juga menjadi landasan yuridis karena mendelegasikan pengaturan izin mendirikan bangunan lebih lanjut dalam bentuk peraturan daerah. Pendelegasian tersebut dalam Pasal 35 ayat (1) yang mengatur bahwa Bupati/Walikota menetapkan peraturan daerah tentang pemberian izin mendirikan bangunan.

c. Undang-Undang Nomor 26 Tahun 2007 tentang Penataan Ruang. Pemerintah Daerah adalah Gubernur, Bupati, atau Walikota, dan perangkat daerah sebagai unsur penyelenggara pemerintahan daerah. Wewenang Pemerintah Daerah kabupaten/kota dalam rangka penataan ruang terdapat dalam Pasal 11 Undang-Undang Nomor 26 Tahun 2007 sebagai berikut :

1) Wewenang Pemerintah Daerah Kabupaten/Kota dalam penyelenggaraan penataan ruang meliputi:

a) Pengauturan, pembinaan, dan pengawasan terhadap pelaksanaan penataan ruang wilayah kabupaten/kota dan kawasan strategis kabupaten/kota;

b) Pelaksanaan penataan ruang wilayah kabupaten/kota;

c) Pelaksanaan penataan ruang kawasan strategis kabupaten/kota; dand.Kerjasama penataan ruang antar kabupaten/kota.

2) Wewenang Pemerintah Daerah Kabupaten/Kota dalam pelaksanaan penataan ruang wilayah Kabupaten/Kota sebagaimana dimaksud pada ayat (1) huruf b meliputi:

a) Perencanaan tata ruang wilayah kabupaten/kota;

b) Pemanfataan ruang wilayah kabupaten/kota; dan

c) Pengendalian pemanfaatan ruang wilayah kabupaten/kota.

3) Dalam pelaksanaan penataan ruang kawasan strategis kabupaten/kota sebagimana dimaksud pada ayat (1) huruf c, Pemerintah Daerah Kabupaten/Kota melaksanakan:

a) Penetapan kawasan strategis kabupaten/kota;

b) Perencanaan tata ruang kawasan strategis kabupaten/kota;

c) Pemnfataan ruang kawasan strategis kabupaten/kota; dan

d) Pengendalian pemanfaatan ruang kawasan strategis kabupaten/kota. 
4) Dalam melaksanakan kewenangan sebagaimana dimaksud pada ayat (1) dan ayat (2), PemerintahDaerah Kabupaten/Kota mengacu pada pedoman bidang penataan ruang dan petunjuk pelaksanaannya.

5) Dalam pelaksanaan wewenang sebagaimana dimaksud pada ayat (1), ayat (2), ayat (3), dan ayat (4), Pemerintah Daerah Kabupaten/Kota :

a) Menyebarluaskan informasi yang berkaitan dengan rencana umum dan rencana rinci tata ruang dalam rangka pelaksanaan penataan ruang wilayah kabupaten/kota; dan

b) Melaksanakan standar pelayanan minimal bidang penataan ruang.Dalam Pemerintah Daerah Kabupaten/Kota tidak dapat memenuhi standar pelayanan minimal bidang penataan ruang, pemerintah daerah provinsi dapat mengambil langkah penyelesaian sesuai dengan ketentuan peraturan perundang-undangan.

6) Undang-Undang Nomor 1 Tahun 2011 tentang Perumahan dan Kawasan Permukiman.

Undang-Undang Republik Indonesia Nomor 1 Tahun 2011 tentang Perumahan dan Kawasan Permukiman (Lembaran Negara Republik Indonesia Tahun 2011 Nomor 7, Tambahan Lembaran Negara Republik Indonesia Nomor 5188), selanjutnya disingkat UndangUndang No. 1Tahun 2011. Perumahan adalah kumpulan rumah sebagai bagian dari permukiman, baik perkotaan maupun perdesaan, yang dilengkapi dengan prasarana, sarana dan utilitas umum sebagai hasil upaya pemenuhan rumah yang layak huni.

Penyelenggaraan rumah dalam Pasal 19 ayat (2) Undang-Undang No. 1Tahun 2011 menyebutkan, "penyelenggaraan rumah dan perumahan sebagaimana dimaksud pada ayat (1) dilaksanakan oleh Pemerintah, Pemerintah Daerah dan/atau setiap orang untuk menjamin hak setiap warga negara untuk menempati, menikmati, dan/atau memilik rumah yang layak dalam lingkungan yang sehat, aman, serasi, dan teratur.

Pemanfaatan rumah dalam Pasal 49 ayat (1) Undang-Undang No. 1 Tahun 2011, menyebutkan "dalam pemanfaatan rumah dapat digunakan sebagai kegiatan usaha secara terbatas tanpa membahayakan dan tidak mengganggu fungsi hunian". Pasal (3) Undang-Undang No. 1 Tahun 2011 menyebutkan, "ketentuan mengenai pemanfaatan rumah sebagaimana dimaksudpada ayat (1) diatur dengan Peraturan Daerah".

\subsection{Analisis Pengendalian Pemanfaatan Ruang Terhadap Pembangunan Perumahan Pada Kawasan Lindung}

Ada beberapa instrumen pengendalian pemanfaatan ruang berdasarkan Peraturan Pemerintah No. 15 Tahun 2010 tentang Penyelenggaraan Penataan Ruang yaitu berupa peraturan zonasi, perizinan, insentif dan disinsentif, dan sanksi administrasi. Sedangkan menurut pengendalian dapat juga dengan pembatasan pemberihan hak atas tanah (Sadyohutomo, 2016: 17) kelembagaan (Hadimoeljono, 2013: 30) dan transparansi informasi Zonasi merupakan alat pengatur yang paling 
banyak digunakan untuk penggunaan lahan yang dilakukan oleh pemerintah daerah baik di tingkat kabupaten maupun kota, karena zonasi dapat mengontrol pembangunan perkotaan, termasuk jenis penggunaan lahan, ruang terbuka dan kepadatan konstruksi.

Instrumen Perizinan terutama perizinan rencana tapak (siteplan) perumahan ada beberapa tahap yang harus dilalui mulai dari penerbitan surat keterangan rencana kota (SKRK), dokumen lingkungan, dokumen andalalin, kajian drainase sampai pada izin mendirikan bangunan (IMB). Dari hasil observasi didapat bahwa seluruh perumahan yang menjadi lokasi penelitian memiliki IMB walaupun secara rencana tata ruang kawasan ini merupakan kawasan lindung (konservasi) bukan untuk kawasan budidaya (hunian). Dari prosedur perizinan bahwa awal alur dari proses perizinan adalah SKRK. Sehingga untuk proses perizinan selanjutnya mengikuti pedoman yang sama. Jika SKRK menyatakan peruntukan pada suatu kawasan untuk Ruang Terbuka Hijau (RTH), maka untuk selanjutnya perizinan tidak dapat diproses.

Instrumen insentif diberikan terutama pada kawasan yang didorong perkembangannya. Pemberian insentif bertujuan agar para pemilik tanah dapat tetap berproduksi karena sebagian besar lahan masih berupa tambak. Insentif yang diberikan berupa pelatihan, bibit dan bangunan nonpermanen. Insentif lain berupa pengajuan ganti rugi oleh pemilik lahan yang ingin menjual tanahnya ke pemerintah kota.

Instrumen disinsentif diberikan pada kawasan yang dibatasi pengembangannya, diantaranya yaitu:

1) Tidak dikeluarkannya IMB untuk perumahan tersebut;

2) Pemberian ganti rugi hanya untuk tanah dan tidak termasuk bangunan, sehingga harga ganti rugi yang nantinya diterima oleh masyarakat lebih rendah dari tanah yang memiliki IMB. Kota dengan prosedur yang lebih ketat untuk mendapatkan izin bangunan atau perubahan zonasi memiliki harga tanah dan rumah yang lebih tinggi;

3) Tidak memberikan akses jalan beraspal atau paving;

4) Tidak memberikan akses layanan air bersih dari PDAM, sehingga masyarakat membeli air bersih dari truk tanki dengan harga yang lebih tinggi. Sedangkan air tanah tidak dapat digunakan untuk keseharian karena rasanya payau;

5) Tidak disediakan taman bermain; dan

6) Tidak mendapat fasilitas KPR karena bank mensyaratkan adanya IMB

Sanksi administratif merupakan instrumen penindakan setelah terjadinya pelanggaran, untuk permasalahan ini pemerintah kota belum melakukan instrument penindakan tersebut (peringatan tertulis, penghentian sementara kegiatan, penghentian sementara pelayanan umum, penutupan lokasi, pencabutan izin, atau pembatalan izin). Hal ini karena secara administrasi bangunan perumahan di kawasan ini tidak memiliki IMB. Sedangkan untuk pembongkaran bangunan juga belum dilakukan dikarenakan untuk melakukan pembongkaran atau pembebasan 
perlu adanya kejelasan rencana kegiatan beserta pendanaannya yang saat ini masih belum ada.

Untuk instrumen pengendalian yang lain yaitu berupa pemberian pembatasan hak atas tanah. Layanan sertifikat tanah untuk kawasan ini belum bisa dikeluarkan jika untuk fungsi budidaya (hunian), karena syarat untuk dikeluarkannya sertifikat diperlukan persyaratan tata ruang untuk memastikan kegiatan yang direncanakan di atas tanah tersebut sesuai dengan tata ruang. Sehingga saat ini BPN menahan proses pemecahan kavling rumah-rumah yang masuk kawasan lindung.

Kelembagaan dan koordinasi dalam pengendalian juga berperan penting. Sejalan dengan hal tersebut, peningkatan kapasitas kelembagaan sangat penting untuk mengelola lebih banyak terutama kota-kota yang mengalami perkembangan yang pesat di negara berkembang. Kapasitas kelembagaan dalam hal ini diimplementasikan dalam upaya penerbitan dengan mekanisme perijinan satu pintu pada Dinas Penanaman Modal (DPM) dan Pelayanan Terpadu Satu Pintu (PTSP) dan melalui perijinan Berusaha Terintegrasi Secara Elektronik atau Online Single Submission (OSS) yang dirasa cukup efektif dalam menekan pelanggaran pemanfaatan ruang. Hal ini dikarenakan memungkinkan terjadinya koordinasi yang lebih intensif antara instansi-instansi yang terkait dalam pemberian izin. Izin yang dikeluarkan oleh masing-masing instansi mengacu pada rujukan yang sama yaitu SKRK, yang mana telah dijelaskan sebelumnya bahwa SKRK mengacu pada Rencana Tata Ruang Wilayah dan peta rincian rencana tata ruang Kabupaten Merauke. Dalam prosedur perizinan sampai dengan dikeluarkannya IMB terdapat pengaturan pembagian tugas sesuai dengan kewenangan instansi terkait (lihat Tabel 1).

Table 1.

Pengaturan Pembagian Tugas Pengendalian Antar Instansi di Kabupaten Merauke

\begin{tabular}{ll}
\hline Izin yang dikeluarkan & Instansi \\
\hline SKRK & $\begin{array}{l}\text { Dinas Perumahan Rakyat dan } \\
\text { Kawasan Permukiman, Cipta Karya } \\
\text { dan Tata Ruang }\end{array}$ \\
\hline Dokumen Lingkungan & Dinas Lingkungan Hidup \\
\hline Dokumen Andalalin & Dinas Perhubungan \\
\hline Kajian drainase & $\begin{array}{l}\text { Dinas Pekerjaan Umum Bina Marga } \\
\text { dan Pematusan }\end{array}$ \\
\hline \multirow{2}{*}{ IMB } & $\begin{array}{l}\text { Dinas Penanaman Modal (DPM) dan } \\
\text { Pelayanan Terpadu Satu Pintu (PTSP) }\end{array}$ \\
\hline
\end{tabular}

Sumber: Data Primer Diolah Penulis Tahun 2020

Instrumen pengendalian lainnya adalah transparansi/ keterbukaan informasi. Dalam upaya pengelolaan penggunaan lahan terkait dengan konsep keadilan administratif dan transparansi, memungkinkan warga dan pemangku kepentingan untuk menyuarakan pendapat mereka dan mendapatkan informasi. Saat ini sudah ada situs resmi berbagai kebijakan rencana tata ruang di Kabupaten Merauke guna mempermudah masyarakat mendapatkan informasi tata ruang. Untuk informasi 
rencana tata ruang ini menjadi satu dengan informasi alur perizinan beserta berbagai dasar hukum yang bisa didownload langsung oleh masyarakat.

Pengendalian pembangunan dapat terlaksana apabila suatu daerah memiliki kriteria pelaksanaan pengendalian pembangunan. Kehandalan pelaksanaan pengendalian pemanfaatan ruang bagi suatu kawasan dapat diperhatikan dari kriteria-kriteria sebagai berikut:

1) Telah tersedia sistem pengendalian pemanfaatan ruang yang dapat menginformasikan secara akurat pelaksanaan pemanfaatan ruang di lapangan.

2) Telah ditempuh mekanisme perijinan yang sesuai dengan rencana tata ruang yang berlaku serta ketentuan dan persyaratan perijinan lainya.

3) Telah dilakukan pemantauan dan evaluasi secara kontinyu terhadap pelaksnaaan program-program pembangunan yang telah direncanakan dalam dokumen rencana tata ruang.

4) Telah dilakukan koreksi dan tindakan perbaikan terhadap penyimpangan pemanfaatan ruang di lapangan sesuai dengan ketentuan yang berlaku.

5) Telah diterapkan instrumen berupa insentif dan disinsentif terhadap suatu arahan kegiatan agar senantiasa sesuai dengan rencana tata ruang.

6) Telah diterapkan sanksi denda terhadap aktor pembangunan yang melanggar pemanfaatan ruang yang tidak sesuai dengan rencana tata ruang yang telah ditetapkan.

\section{Kesimpulan}

Pemerintah Daerah memiliki kewenangan untuk mengatur, dan menyeimbangkan penataan bangunan agar masyarakat memiliki izin mendirikan bangunan yang sesuai dengan bangunan saat ini. Kewenangan yang diberikan kepada pemerintah daerah untuk mengatur dan menyeimbangkan daerah itu diberikan berdasarkan asas desentralisasi, dekonsentrasi, dan tugas pembantuan. Pengaturan bangunan dan gedung dapat diklarifikasikan sebagai bagian pelayanan dasar dibidang pekerjaan umum dan penataan ruang. Pembagian urusan pemerintahan dibidang pekerjaan umum dan penataan ruang, urusan bangunan gedung serta penataan bangunan dan lingkungannya menjadi salah satu urusan wajib pemerintahan daerah. Dua urusan tersebut menjadi dasar yuridis bagi pemerintah daerah untuk mengaturnya dalam peraturan daerah. Urusan wajib yang menjadi urusan kabupaten/kota adalah penyelenggaraan bangunan gedung, yang termasuk dalam hal ini adalah pengaturan pemerintah dalam izin mendirikan bangunan (IMB) dan sertifikat laik fungsi (SLF) bangunan gedung baru. Pelaksanaan alih fungsi kawasan lindung di Kelurahan Samkai tidak sesuai arahan ruang saat ini. Untuk itu pemerintah daerah Kabupaten Merauke dalam kewenangannya mengatur menyeimbangkan penataan bangunan di kawasan konservasi dan kawasan resapan air agar masyarakat memiliki izin mendirikan bangunan yang sesuai dengan bangunan saat ini. Sehingga ketika masyarakat ingin menambahkan, merubah dan membangun bangunan yang baru maka harus terlebih dahulu memiliki izin mendirikan bangunan (IMB). Bagi masyarakat yang melanggar pelaksanaan 
pengaturan perizinan dalam mendirikan suatu bangunan akan dikenakan sanksi. Sanksi administratif bagi pelanggaran ketentuan peraturan daerah IMB mencakup peringatan tertulis, denda administratif, pembekuan IMB, pencabutan IMB, pembongkaran bangunan, tetapi dalam upaya pengendalian maupun menertibkan perumahan skala kecil tersebut pemerintah daerah masih menghadapi berbagai kendala/hambatan, yaitu Belum memiliki peraturan daerah tentang rencana strategis (renstra) kawasan lindung sehingga pemerintah belum dapat memberikan kepastian ke masyarakat mengenai rencana kegiatan dan pembiayaan pada lokasi perumahan tersebut. Pengawasan dan pengendalian masih bersifat pasif karena hanya berdasarkan pengaduan dan tidak dilakukan secara berkala. Sebagian besar tanah dikawasan lindung tersebut milik swasta dan masyarakat, sehingga pengendalian hanya sebatas himbauan. Petugas yang selalu berganti sehingga informasi tidak tersampaikan ke petugas yang baru. Perumahan tersebut sudah terlayani prasarana jalan dan listrik sehingga memberikan kenyamanan tersendiri bagi masyarakat

\section{Daftar Referensi}

Arisaputra, M. I. (2015). Reforma Agraria Di Indonesia. Sinar Grafika.

Hadimoeljono, B. (2013). Pengendalian Pemanfaatan Ruang: Mencari Kelembagaan Pemanfaatan Ruang yang Efektif. Direktortat Tata Ruang dan Pertanahan Bappenas.

Sadyohutomo, M. (2016). Tata Guna Tanah dan Penyerasian Tata Ruang. Pustaka Pelajar.

Saleng, A. (2013). Kapita Selekta Hukum Sumberdaya Alam. Membumi Publishing.

Soedarso, B. P. (1990). Meningkatnya Penguasaan dan Pemahaman Mengenai Tata Ruang dan Pengaturan Hukumnya. Jurnal Hukum \& Pembangunan, 20(4), 385390. https:/ / doi.org/10.21143/jhp.vol20.no4.922

Wahid, A. M. Y. (2016). Pengantar Hukum Tata Ruang. Prenadamedia Group. 